СД-7.

\title{
ЭЛЕКТРОХИМИЧЕСКИЙ СЕНСОР ДЛЯ ОПРЕДЕЛЕНИЯ ОН-РАДИКАЛОВ В БИОЛОГИЧЕСКИХ ОБЪЕКТАХ
}

Гераскевич А.В.

Национальный исследовательский Томский политехнический университет, Томск, Россия avg48@tpu.ru

DOI: 10.26902/ASFE-11_100

Гидроксильный радикал является одной из наиболее губительных активных форм кислорода в организме человека и выступает в качестве основного маркера окислительного стресса, который имеет особое значение в развитии ряда патологий, в том числе и раковых заболеваний [1]. В связи с этим измерение уровня ОН-радикалов в биологических объектах является актуальной задачей, поскольку полученные данные позволяют судить не только об уровне окислительного стресса, но и об эффективности действия антиоксидантных препаратов.

Электрохимический сенсор для определения $\mathrm{OH}^{*}$, разработанный в данной работе, представляет собой графитовый электрод, импрегнированный парафином и полиэтиленом, с последовательно нанесенными золотой пленкой и 1-гексантиолом. Самоорганизующийся монослой алкантиола, образованный на поверхности рабочего электрода за счет хемосорбции атома серы на золоте, разрушается при воздействии гидроксильных радикалов, что приводит к появлению аналитического сигнала, который регистрируется методом импедансной спектроскопии.

Исследование поверхности рабочего электрода проводилось после каждого этапа модификации методами импедансной спектроскопии и циклической вольтамперометрии. Измерения проводились в $5 \mathrm{MM}\left[\mathrm{Fe}(\mathrm{CN})_{6}\right]^{3-/ 4-}$ в $0,1 \mathrm{M} \mathrm{KCl}$.

Импедансные спектры немодифицированного рабочего электрода и его модификаций соответствуют модели Рэндлса. Сопротивление переноса заряда $\left(R_{\mathrm{ct}}\right)$, рассчитанное из эквивалентной схемы, составляет 10000 Ом для немодифицированного графитового электрода. После нанесения золота значение $R_{\mathrm{ct}}$ уменьшается до 90 Ом, что указывает на крайне быстрый процесс переноса электрона. Однако после обработки 1-гексантиолом происходит увеличение $R_{\mathrm{ct}}$ до 2596 Ом, что подтверждает образование монослоя алкантиола на поверхности электрода.

Электроактивные площади немодифицированного графитового электрода, а также его модификаций с золотом и 1-гексантиолом были рассчитаны по уравнению Рэндлса-Шевчика для обратимого процесса. Электроактивная площадь немодифицированного графитового электрода составила $0,119 \mathrm{~cm}^{2}$. Модификация электрода золотом вызвала увеличение электроактивной площади до $0,213 \mathrm{~cm}^{2}$, а последующее нанесение алкантиола уменьшило ее значение до $0,0936 \mathrm{~cm}^{2}$.

Концентрация 1-гексантиола на поверхности сенсора была определена методом хроноамперометрии. Поверхностная концентрация алкантиола составила $1,95 \cdot 10^{-7}$ моль $/ \mathrm{cm}^{2}$, что является достаточной величиной для получения аналитического сигнала.

Таким образом, полученные данные позволяют исследовать работу сенсора на модельной системе на основе реакции Фентона.

\section{Список литературы}

1. Vera-Ramirez L. et al. // Critical reviews in oncology/hematology. 2011. T. 80. №. 3. C. 347-368.

Работа выполнена при финансовой поддержке ГЗ «Наука» № FSWW-2020-0022 и РФФИ в рамках научного проекта № 19-53-26001. 